\title{
Torrubiella dimorpha, a new species of spider parasite from Taiwan
}

\author{
S. S. TZEAN*, L. S. HSIEH AND W. J. WU \\ Department of Plant Pathology and Entomology, National Taiwan University, Taipei, Taiwan 10617, R.O.C.
}

Torrubiella dimorpha sp. nov. on an infected spider from Taiwan is described and illustrated. It is characterized by producing perithecia on an orange white, pulvinate, lanose mycelial mat covering the host. The anamorph, Gibellula dimorpha sp. nov., produces gibelluloid and granulomoid synanamorphs on aspergillate, distinctly roughened or warty conidiophores, or sometimes produces both synanamorphs on the same aspergillate vesicle. The differences between T. dimorpha and the closely related T. globosa, T. globoso-stipitata, T. arachnophila, T. ratticaudata and T. clavata are briefly discussed.

Torrubiella was established in France (Boudier, 1885) to accommodate a single species Torrubiella arachnida Boud. on a spider. Since then many new taxa of Torrubiella parasites on spiders, coccids, leaf hoppers, ants, moths, psyllids, and on Cordyceps species have been described (Petch, 1923, 1932, 1944; Mains, 1950; Samson \& Evans, 1973, 1977, 1992; Kobayasi \& Shimizu, 1976, 1982; O’Donnell, Common \& Imshaug, 1977; Humber \& Rombach, 1987; Samson, ReenenHoekstra van \& Evans, 1989; Hywel-Jones, 1993, 1995). Kobayasi (1982) provided keys to Cordyceps and Torrubiella. Kobayasi \& Shimizu (1982) also monographed the 56 valid species of Torrubiella. Thirty-four species were described from spiders and only four of these produced Gibellula anamorphs, including T. globosa Kobayasi \& Shimizu, T. globoso-stipitata Kobayasi \& Shimizu, T. arachnophila (J. R. Johnst.) Mains, and T. gibellulae Petch (Petch, 1932; Mains, 1950; Kobayasi \& Shimizu, 1982). More recently, T. ratticaudata Humber \& Rombach was described from salticid spiders from the Solomon Islands; its anamorph, Gibellula clavulifera (Petch) Samson \& H. C. Evans var. alba Humber \& Rombach, was characterized by ovoid conidia on phialidic conidiogenous cells borne on penicillate conidiophores, and bacilliform conidia initiated from polyblastic conidiogenous cells arising directly from the mycelium (Humber \& Rombach, 1987). Torrubiella clavata Samson \& H. C. Evans was described from Araneida on cacao (Theobroma cacao L.) from western Ecuador; its anamorph G. clavata Samson \& H. C. Evans, produced unique broadly clavate, solitary, occasionally paired synnemata, and the gibelluloid morph having short, distinctly roughened conidiophores and the granulomanoid morph having one-celled ovalcylindrical conidiogenous cells arising from irregular branched hyphae or on short branches (Samson \& Evans, 1992). Nonetheless, the taxonomy of Torrubiella was problematic

* Corresponding author. because many specimens collected have been immature or at different developmental stages, and also because the distinguishing characters were few. It has been stressed that the presence or absence of anamorph is crucial for distinction of the species of the genus (Mains, 1950; Samson, ReenenHoekstra van \& Evans, 1989).

During a survey of the entomopathogenic fungi from Taiwan, which has been in progress since 1989, a total of 117 spider cadavers infected by fungal pathogens was collected. Of these, 11 specimens were infected by Torrubiella spp., two T. flava Petch, one T. gonylepticida (F. H. Møller) Petch, two T. minutissima Kobayasi \& Shimizu, two T. tenuis Petch, and three T. luteorostrata Zimm. (Petch, 1923; Kobayasi \& Shimizu, 1982). One was infected by a Torrubiella species with gibelluloid and granulomanoid synanamorphs which was different from the known Torrubiella species from spiders with Gibellula anamorphs (Kobayasi \& Shimizu, 1981, 1982; Humber \& Rombach, 1987; Samson \& Evans, 1992), and is described here as a new species. Colour nomenclature follows Kornerup \& Wanscher (1978).

Torrubiella dimorpha Tzean, L. S. Hsieh \& W. J. Wu sp. nov. (Figs 1-17) Anamorph: Gibellula dimorpha Tzean, L. S. Hsieh \& W. J. Wu sp. nov.

Hospes aranea infecta tegete densa, myceliali, alba, eburnea vel aurantialba (4-5A2), pulvinata, tomentosa vel lanosa, margine praedito patenti, subiculum byssoideum formanti, obtectus. Hyphae ramosae, septatae, hyalinae, distincte verrucosae, interdum laevi-tunicatae, $2 \cdot 4-5 \cdot 6 \mu \mathrm{m}$ latae. Perithecia in tegete myceliali producta, superficialia vel subinclusa, aspersa, ovoidea, 490-600 × 250-320 $\mu \mathrm{m}$, eburnea (1-2A2), tomentosa, parietibus $12-18 \mu \mathrm{m}$ crassis praedita. Asci octospori, cylindrici, $6 \cdot 4-8 \cdot 2 \mu \mathrm{m}$ lati, pileo incrassato $4 \cdot 8-6 \cdot 4 \mu \mathrm{m}$ crasso 6.8-8.7 um lato praedita. Ascosporae filiformes, multiseptatae, in seriebus parallele dispositae, $1 \cdot 6-2 \cdot 4 \mu \mathrm{m}$ latae, in partisporas abrumpentes. Partisporae cylindricae, truncatae, laeves, hyalinae, 3-8.7 $\times 2-2.3 \mu \mathrm{m}$. Synnemata solitaria, e tegete myceliali exorientia, 


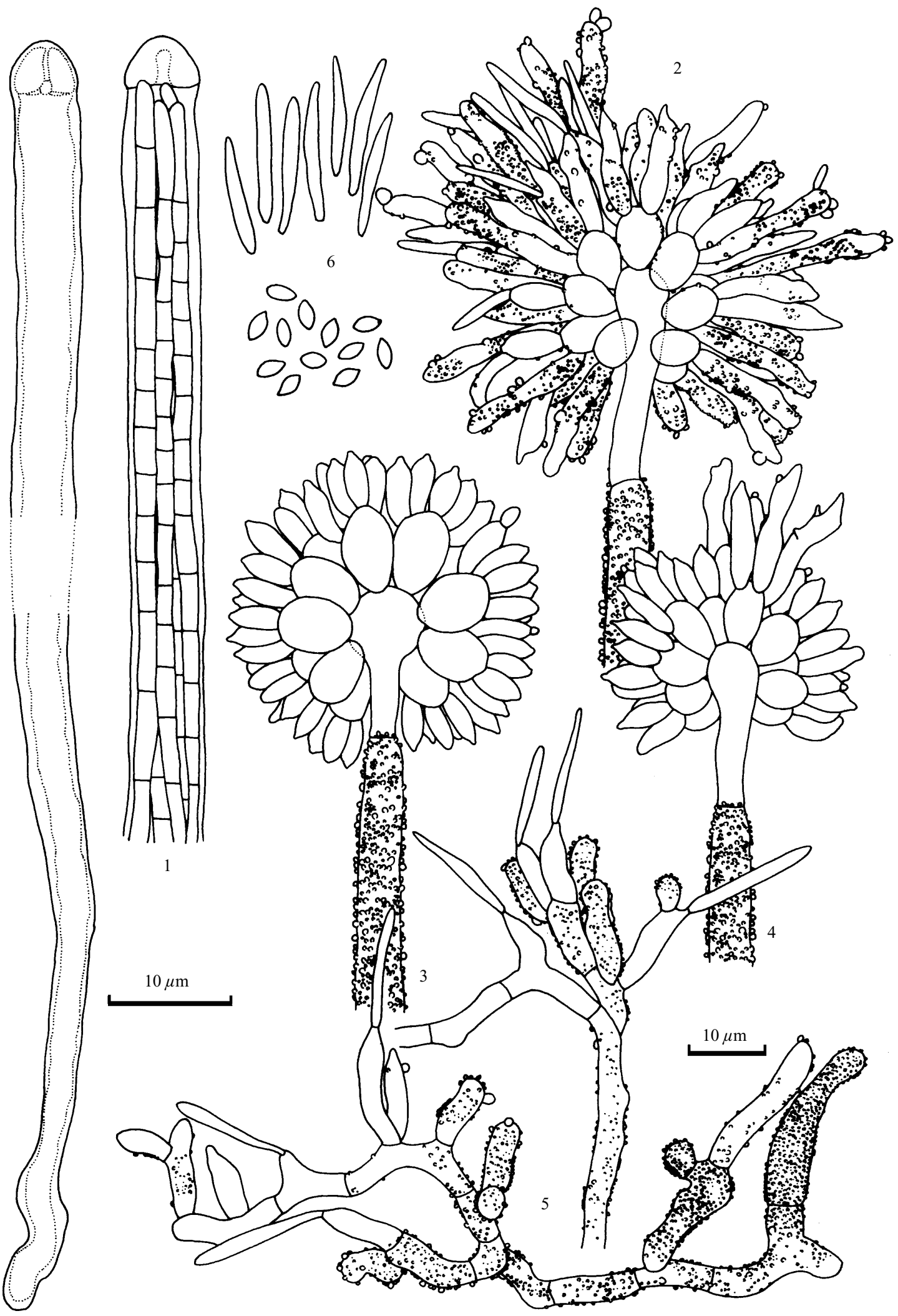

Figs 1-6. Torrubiella dimorpha. Fig. 1. Ascus with thickened ascal apex and part of ascospores. Fig. 2. Granulomanoid vesicle. Fig. 3. Gibelluloid conidiophore. Fig. 4. Gibellula vesicle bearing gibelluloid and granulomanoid conidiogenous cells. Fig. 5. Granulomanoid conidiophores irregular, branched, bearing conidiogenous cells and conidia. Fig. 6. Granulomanoid and gibelluloid conidia.

cylindrica, attenuata, curva, $5 \mathrm{~mm} \times 200 \mu \mathrm{m}$, e hyphis compactis longitudinaliter septatis composita, hyalina, laevia, raro exasperata, 2:2-4 $\mu \mathrm{m}$. Conidiophora status Gibellulae mono-vel synnematica, chloroleuca vel pallide viridia $(30 \mathrm{A2}-3), 140-422 \times 7 \cdot 1-10 \cdot 3 \mu \mathrm{m}$, septis incrassatis, conspicuis, saepe atro-pigmentosis praedita, base distincte exasperata, verrucata, in apicem gracilem, laevi-tunicatum $3 \cdot 2-4 \cdot 5 \mu \mathrm{m}$ latum abrupte astricta, in vesiculam tumidam terminantia. Caput conidiale sphaericum, diametro $36-54 \mu \mathrm{m}$. Vesicula globosa vel 

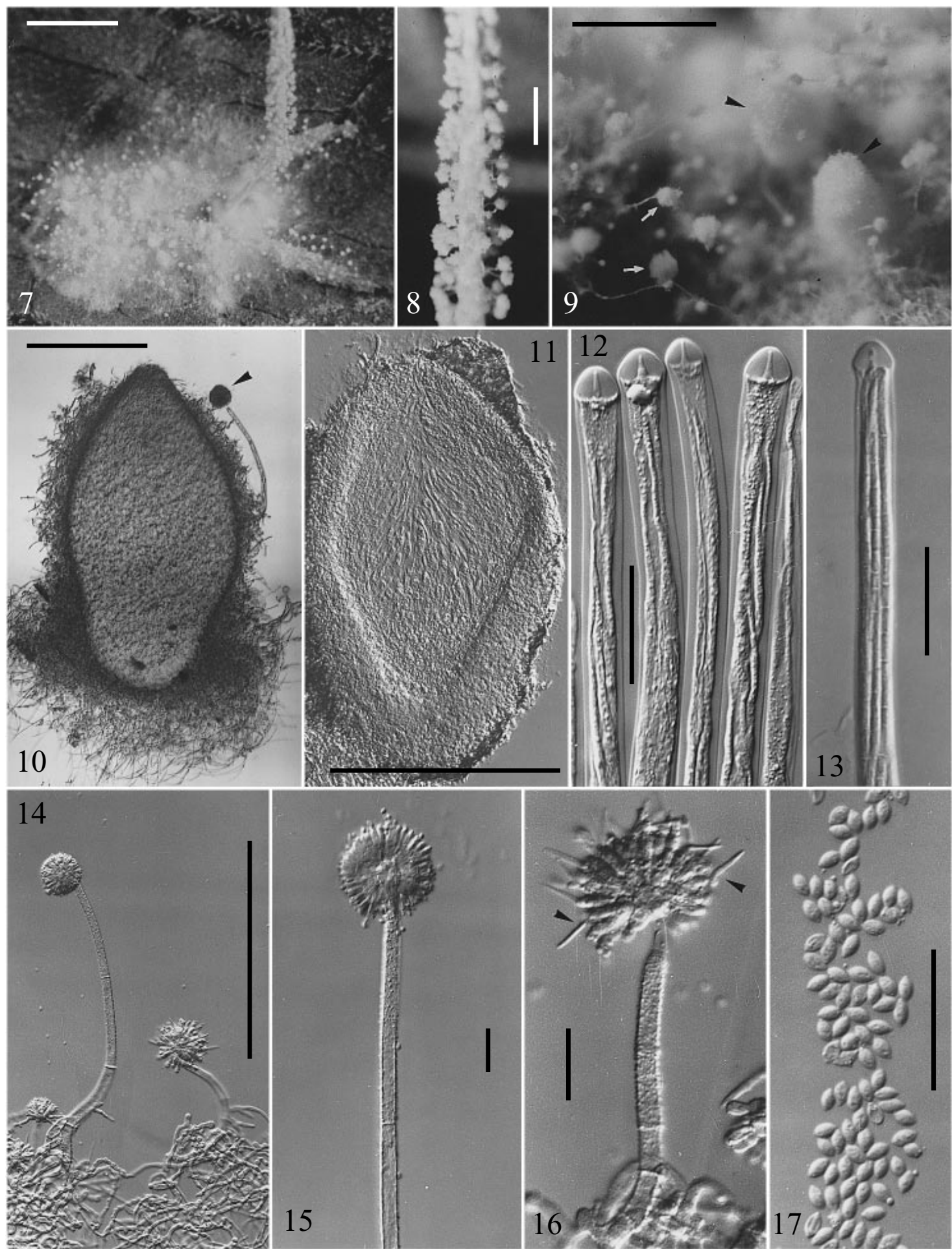

Figs 7-17. Torrubiella dimorpha. Fig. 7. Habit of spider infected by Torrubiella dimorpha. Fig. 8. Synnema and conidiogenous head. Fig. 9. Production of conidial heads (arrows) and perithecia (arrow heads) from the mycelium or weft of interwoven hyphae. Fig. 10. Perithecium with an anamorphic conidiophore, bearing conidial head (arrow head). Fig. 11. Perithecium and asci. Fig. 12. Thickened ascal apex. Fig. 13. Part of mature ascus and ascospores. Fig. 14. Coexistence of gibelluloid and granulomanoid conidiophores and conidiogenous structures. Fig. 15. Gibelluloid conidiophore and conidiogenous structures. Fig. 16. Granulomanoid conidiophore and conidiogenous structures, and filiform conidia (arrow heads). Fig. 17. Gibelluloid conidia. Scale bars: Fig. $7=2 \mathrm{~mm}$; Figs $8,9=$ $500 \mu \mathrm{m}$; Figs $10,11,14=200 \mu \mathrm{m}$; Figs $12,13,15-17=20 \mu \mathrm{m}$.

subglobosa, diametro $7 \cdot 9-11 \cdot 1 \mu \mathrm{m}$. Phialides cylindricae vel anguste clavatae, collo brevi saepe in apice incrassato praeditae, laeves, hyalinae, 5.6-8.7 $\times 2.5-4 \mu \mathrm{m}$, usque ad 21. Metulae late obovoidea, basem versus angustatae, hyalinae, $7 \cdot 1-11 \cdot 9 \times 6 \cdot 4-8 \cdot 7 \mu \mathrm{m}$, usque ad 27. Conidia plerumque ellipsoidea vel limoniformia, hyalina, laevi- tunicata, unica vel catenata, $3 \cdot 2-4 \cdot 1 \times 2-2 \cdot 4 \mu \mathrm{m}$. Conidiophora morphae status Granulomani praesentia, capite conidiali metulas dense verticillatas (usque ad 20) et cellulas polyblasticas conidiogenas ferenti praedita, exasperata vel distincte verrucosa, $68-140 \times 5 \cdot 2-$ $7 \cdot 1 \mu \mathrm{m}$, interdum hyphis ramosis cellulas solitarias, polyblasticas, 
conidiogenas ferentibus praedita. Metulae late obovoideae, 5.6$8.7 \times 4 \cdot 4-6.4 \mu \mathrm{m}$, laeves, interdum minute verruculatae. Cellulae conidiogenae cylindricae, ellipsoideae, anguste clavatae, conoideae vel irregulariter formatae, $7 \cdot 9-20 \cdot 6 \times 3 \cdot 2-4 \mu \mathrm{m}$, laeves, interdum exasperatae, denticulos $1-3$ conspicuos ferentes. Conidia filiformia, laevi-tunicata, hyalina, 9.1-23.8 $\times 0.8-2 \cdot 4 \mu \mathrm{m}$. Aliquando, granulomanoid conidiogenesia evenit in eadem conidiophora morphae status gibelluloid.

Holotypus in araneo, Arachnida, Liukui, Shanping, Comitatus Kaohsiung, Taiwan, 22 Oct, 1994, PPH Ar. 80.

Infected spider host covered with dense mycelial mat, white, yellowish white to orange white (4-5A2), pulvinate, tomentose, lanose, margin spreading, forming byssoid subiculum. Hyphae branched, septate, hyaline, distinctly verrucose, sometimes smooth-walled, $2 \cdot 4-5 \cdot 6 \mu \mathrm{m}$ wide. Perithecia produced on mycelial mat, superficial or partly embedded, scattered, ovoid, 490-600 × 250-320 $\mu \mathrm{m}$, yellowish white (12A2), tomentose, perithecial wall 12-18 $\mu \mathrm{m}$ thick. Asci eightspored, cylindrical, $220-310 \times 6 \cdot 4-8 \cdot 2 \mu \mathrm{m}$, with a thickened perforated apex, 4.8-6.4 $\mu \mathrm{m}$ high, 6.8-8.7 $\mu \mathrm{m}$ wide. Ascospores filiform, multiseptate, arranged in parallel rows, $1 \cdot 6-2 \cdot 4 \mu \mathrm{m}$ wide, breaking into part-spores. Part-spores cylindrical, truncate, smooth, hyaline, 3-8.7 $\times 2-2 \cdot 3 \mu \mathrm{m}$. Synnemata solitary, arising from mycelial mat, cylindrical, attenuated, curved, $5 \mathrm{~mm} \times 200 \mu \mathrm{m}$, consisting of compacted septate longitudinal hyphae, hyaline, smooth, rarely roughened, $2 \cdot 2-4 \mu \mathrm{m}$ wide. Conidiophores for the gibelluloid state, arising from the mycelium or synnemata, greenish white to pale green (30A2-3), 140-422 × 7·1-10.3 $\mu \mathrm{m}$, septa thickened, conspicuous, often darkly pigmented, base distinctly roughened, warty, narrowing abruptly to a slender, smooth-walled apex, $3 \cdot 2-4 \cdot 5 \mu \mathrm{m}$ wide, terminating in a swollen vesicle. Conidial head spherical, 36-54 $\mathrm{mm}$ diam. Vesicle globose to subglobose,

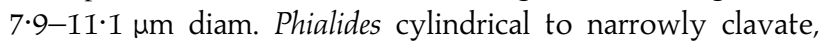
with a short neck, often apically thickened, smooth, hyaline, $5 \cdot 6-8.7 \times 2.5-4 \mu \mathrm{m}$, numerous, borne on metulae, up to 21 . Metulae broadly obovoid, narrowing towards base, hyaline, $7 \cdot 1-11 \cdot 9 \times 6 \cdot 4-8 \cdot 7 \mu \mathrm{m}$, numerous, borne on vesicle, up to 27 . Conidia fusoid, ellipsoidal or lemon-shaped, hyaline, smoothwalled, single or catenate, $3 \cdot 2-4 \cdot 1 \times 2-2 \cdot 4 \mu \mathrm{m}$. Granulomanoid morph conidiophores present, spherical conidial head bearing densely whorled metulae (up to 20) and polyblastic conidiogenous cells, roughened to distinctly verrucose, 68-140 $\times$ $5 \cdot 2-7 \cdot 1 \mu \mathrm{m}$, sometimes with branched hyphae bearing solitary, polyblastic conidiogenous cells. Metulae broadly obovoid, $5 \cdot 6-8 \cdot 7 \times 4 \cdot 4-6 \cdot 4 \mu \mathrm{m}$, smooth, occasionally minutely warted. Conidiogenous cells cylindrical, ellipsoidal, narrowly clavate, conoid, or irregularly shaped, $7 \cdot 9-20.6 \times 3 \cdot 2-4 \mu \mathrm{m}$, smooth, sometimes roughened, bearing 1-3 conspicuous denticles. Conidia filiform, smooth-walled, hyaline, 9.1-23.8 $\times 0.8-$ $2 \cdot 4 \mu \mathrm{m}$. Sometimes, the granulomanoid conidiogenesis occurring on the same conidiophore with the gibelluloid state.

Specimen examined: on spider (Arachnida), Liukui, Shanping, Kaohsiung County, Taiwan, R.O.C., 22 Oct., 1994, holotype PPH Ar. 80 (dried specimen) deposited in the Department of Plant Pathology and Entomology, National Taiwan University, Taipei, Taiwan, R.O.C.

Torrubiella dimorpha is characterized by scattered, yellowishwhite, tomentose, ovoid, perithecia arising from an orange white, pulvinate, lanose mycelium mat. The anamorph, Gibellula dimorpha, produced gibelluloid and granulomanoid synanamorphs on aspergillate, distinctly roughened or warty conidiophores. Occasionally, the aspergillate conidial head bore phialidic and polyblastic conidiogenous cells on the same vesicle. Humber \& Rombach (1987), while describing G. clavulifera var. alba, synonymized the form genus Granulomanus with Gibellula, because both typical gibelluloid conidiophores and sessile polyphialides bearing bacilliform conidia, which is characteristic of granulomanoid morph, can occur on the same hyphae covering the infected spider host. Also, the Granulomanus form almost never occurs in the absence of Gibellula and/or its teleomorphic, Torrubiella (Humber \& Rombach, 1987). In G. dimorpha, the granulomanoid conidia being produced on a same conidiophore that is otherwise mainly gibelluloid. The same event also occurs in a recent described Gibellula unica Tzean, L. S. Hsieh \& W. J. Wu, in which the phialidic or polyblastic conidiogenous cells of, respectively, Gibellula and Granulomanus, are concurrently or independently produced on the same well differentiated distinctly verrucose conidiophores (Tzean, Hsieh \& Wu, 1997). The evidence presumably supports the concept of Humber \& Rombach (1987) in synonymization of these two synanamorphic genera. The synopsis of the synanamorphs differed from the six known species of Torrubiella that parasitize spiders and produced only the gibelluloid morph (Petch, 1932; Mains, 1950; Kobayasi \& Shimizu, 1982) or together with a granulomanoid morph (Humber \& Rombach, 1987; Samson \& Evans, 1992). Torrubiella dimorpha can be readily separated from $T$. globosa, T. globoso-stipitata, $T$. gibellulae and $T$. arachnophila by the morphological characteristics of the gibelluloid anamorph. No granulomanoid morph has been described for the latter four species. In addition, the part-spores of these four species are about $3-5 \times 1-1.5 \mu \mathrm{m}$; and narrower and usually shorter than partspores of T. dimorpha, 3-8.7 $\times 2-2.3 \mu \mathrm{m}$. The single synnemata of $T$. ratticaudata are long and slender $(15 \times 0.5 \mathrm{~mm})$, whiplashlike, and whilst the sterile, granulomanoid morph is mostly penicillate. In contrast, in T. clavata the synnemata are broadly clavate, with a sterile basal stipe and fertile terminal region, produced singly or in pairs, and the conidiophores of the gibelluloid morphs were considerably shorter, $30-50 \mu \mathrm{m}$ in length. The conidiophores of the granulomanoid morph of $T$. clavata consisted of irregular branched hyphae, bearing solitary, polyblastic conidiogenous cells. The microscopic conidial apparatus of $T$. ratticaudata and $T$. clavata sharply contrasts with that of $T$. dimorpha, which possess cylindrical, subulate synnemata, fertile along the whole length, and the gibelluloid and granulomanoid morphs were usually axpergillate. Also the conidiogenous cells of the granulomanoid morph were distinctly roughened and warty. The anamorph of T. dimorpha, G. dimorpha, somewhat resembles G. unica Tzean, L.S. Hsieh \& W. J. Wu, described from a spider specimen collected from Taiwan (Tzean, Hsieh \& Wu, 1997). Rarely G. unica also produced gibelluloid and granulomanoid morphs on the same sporulating apparatus. In G. unica, however, no teleomorph has been found and the conidia of its gibelluloid morph were fusiform $(4-6.8 \times 1 \cdot 6-2.2 \mu \mathrm{m})$ in contrast to the predominantly ellipsoidal conidia $(3 \cdot 2-$ 
$4 \cdot 1 \times 2-2 \cdot 4 \mu \mathrm{m})$ of $G$. dimorpha. The synnemata of $G$. brunnea Samson \& H. C. Evans have a short, stout, yellow-tan stipe $(0.2-0.8 \times 0.2-0.4 \mathrm{~cm})$, which widens into a lateral, globose to pyriform $(0.5-0.8 \times 0.8-1.4 \mathrm{~cm})$ fertile head, and narrows into a pale brown, compact accuminate stipe tip. These features readily distinguish from the cylindrical, attenuated, curved, apparently shorter and narrower synnemata $(5 \mathrm{~mm} \times 200 \mu \mathrm{m})$ of $G$. dimorpha, although both species show some similarity in having distinctly roughened or warty conidiophores.

The research was supported by grants from National Science Council (NSC84-2321-13002-129) and Council of Agriculture [84 Ko-Chi-1·3-Liang-31(8-2)], Taiwan, R.O.C. The authors are indebted to Dr Richard A. Humber for critical review and constructive comments on the manuscript; and Ms P. Eckel for preparation of the Latin diagnosis.

\section{REFERENCES}

Boudier, E. (1885). Note sur un nouveau genre et quelques nouvelles espèces des Pyrénomycètes. Revue Mycologique 7, 224-277, pl. 56.

Humber, R. A. \& Rombach, M. C. (1987). Torrubiella ratticaudata sp. nov. (Pyrenomycetes: Clavicipitales) and other fungi from spiders on the Solomon Islands. Mycologia 79, 375-382.

Hywel-Jones, N. L. (1993). Torrubiella luteorostrata: a pathogen of scale insects and its association with Paecilomyces cinnamomeus with a note on Torrubiella tenuis. Mycological Research 97, 1126-1130.

Hywel-Jones, N. L. (1995). Torrubiella iriomoteana from scale insects in Thailand and a new related species Torrubiella siamensis with notes on their respective anamorphs. Mycological Research 99, 330-332.
Kobayasi, Y. (1982). Key to the taxa of the genera Cordyceps and Torrubiella. Transaction of the Mycological Society of Japan 23, 329-364.

Kobayasi, Y. \& Shimizu, D. (1976). Some species of Cordyceps and its allies on spiders. Kew Bulletin 31, 557-566.

Kobayasi, Y. \& Shimizu, D. (1981). The genus Cordyceps and its allies from Taiwan (Formosa). Bulletin of National Science Museum, Tokyo, Series B, 7, 113-122.

Kobayasi, Y. \& Shimizu, D. (1982). Monograph of the genus Torrubiella. Bulletin of National Science Museum, Tokyo, Series B, 8, 43-78.

Kornerup, A. \& Wanscher, J. H. (1978). Methuen Handbook of Colour. Eyre Methuen Ltd.: London, U.K.

Mains, E. B. (1950). The genus Gibellula on spiders in North America. Mycologia 42, 306-321.

O'Donnell, K. L., Common, R. S. \& Imshaug, H. A. (1977). A new species of Torrubiella on a spider from the Falkland Islands. Mycologia 69, 618-622.

Petch, T. (1923). Studies in the entomogenous fungi. Transaction of the British Mycological Society 9, 108-129.

Petch, T. (1932). Gibellula. Annals of Mycology 30, 386-393.

Petch, T. (1944). Notes on entomogenous fungi. Transaction of the British Mycological Society 27, 81-93.

Samson, R. A. \& Evans, H. C. (1973). Notes on entomogenous fungi from Ghana. I. The genera Gibellula and Pseudogibellula. Acta Botanica Neerlandica 22, 522-528.

Samson, R. A. \& Evans, H. C. (1977). Notes on entomogenous fungi from Ghana. IV. The genera Paecilomyces and Nomuraea. Proceedings of the Koninklijke Nederlandse Akademie van Wetenschappen, Series C, 80, 128-134.

Samson, R. A. \& Evans, H. C. (1992). New species of Gibellula on spiders (Araneida) from South America. Mycologia 84, 300-314.

Samson, R. A., Reenen-Hoekstra van, E. S. \& Evans, H. C. (1989). New species of Torrubiella (Ascomycotina: Clavicipitales) on insects from Ghana. Studies in Mycology 31, 123-132.

Tzean, S. S., Hsieh, L. S. \& Wu, W. J. (1997). The genus Gibellula on spiders from Taiwan. Mycologia 89, 309-318. 